Berkala Ilmu Perpustakaan dan Informasi, Vol. 15, No. 1, Juni 2019, Hal. 34-47 DOI: 10.22146/bip.39370

ISSN 1693-7740 (Print), ISSN 2477-0361 (Online)

Tersedia online di https://jurnal.ugm.ac.id/bip

\title{
Kepuasan mahasiswa terhadap layanan sumberdaya Perpustakaan Universitas Sumatera Utara
}

\author{
Jonner Hasugian ${ }^{1}$ \\ ${ }^{1}$ Program Studi IImu Perpustakaan, Universitas Sumatera Utara \\ e-mail:jonner@library.usu.ac.id
}

\begin{abstract}
Naskah diterima: 03 Oktober 2018, direvisi: 19 Maret 2019, disetujui: 18 April 2019
\end{abstract}
\begin{abstract}
ABSTRAK
Pendahuluan. Faktor sosio-demografi pemustaka seperti jenis kelamin, usia, adakalanya berpengaruh terhadap penggunaan sumber daya informasi. Faktor tersebut sering digunakan sebagai variabel anteseden dalam meneliti penggunaan sumber daya informasi di perpustakaan. Penelitian ini bertujuan untuk mengetahui kepuasan yang diinginkan dan kepuasan yang diperoleh mahasiswa dari penggunaan sumber daya informasi tercetak dan elektronik di Perpustakaan Universitas Sumatera Utara (USU).

Metode penelitian. Penelitian menggunakan metode survei dengan pendekatan kuantitatif. Sampel ditetapkan menggunakan rumus Taro Yamane. Kuesioner digunakan untuk menjaring data yang diperlukan.

Data analisis. Pengolahan data menggunakan program aplikasi Lisrel versi 8.8. Analsis data menggunakan statistik Chi-Kuadrat, multivariate analysis of variance dan analisis jalur.

Hasil dan Pembahasan. Tidak terdapat perbedaan yang signifikan dalam penggunaan sumber daya informasi berdasarkan jenis kelamin pemustaka. Tidak terdapat kesenjangan yang signifikan antara kepuasan yang diinginkan dengan kepuasan yang diperoleh dari penggunaan sumber daya informasi berdasarkan jenis kelamin pemustaka. Penggunaan sumber daya informasi tercetak dan elektronik yang tersedia di Perpustakaan USU memuaskan mahasiswa baik laki-laki maupun perempuan.

Kesimpulan dan Saran. Faktor sosio demografis jenis kelamin tidak signifikan berpengaruh terhadap penggunaan sumber daya informasi tercetak maupun elektronik di Perpustakaan USU. Mahasiswa USU sangat heterogen terdiri dari beragam suku dan enik, disarankan penelitian lanjutan dengan variabel anteseden berdasarkan suku atau etnik.
\end{abstract}

Kata Kunci: Kepuasan yang dicari; Kepuasan yang diperoleh; Sumber daya informasi

\section{ABSTRACT}

Introduction. Socio-demographic factors, such as gender and age, may affect the use of information resources for library users. These factors are often used as the antecedent variables in examining the use of information resources in the library. The purpose of research was to determine the expected and obtained satisfaction of students using printed and electronic information sources at Universitas Sumatera Utara Library.

Data Collection Method. This study used a quantitative approach by using questionnaires. The sample was taken by using Taro Yamane formula.

Data Analysis. The data processing used Lisrel version 8.8, Chi-Square statistics, multivariate analysis of variance and path analysis.

Results and Discussions. Among male and female students, there was no significant difference in using of information resources and no significant discrepancy between expected and obtained satisfactions. The printed and electronic information resources were available at USU Library to satisfy both gender.

Conclusions. Socio-demographic factors of gender has no significant effect in using printed and electronic information resources at USU Library. Future research should discuss other antecedent variables such as ethnicity.

Keywords: Gratification sought; Gratification obtained; Information resources. 


\section{A. PENDAHULUAN}

Kehadiran teknologi berdampak luas terhadap dunia penerbitan dan perpustakaan. Ketika Johannes Gutenberg menemukan mesin cetak pada tahun 1456 yang lampau, terjadi perubahan yang mengubah banyak hal dalam dunia penerbitan (Zimmerman, 2010). Bagi perpustakaan penemuan itu dimaknai dengan munculnya cara baru untuk merekam dan menyebarluaskan informasi dan pengetahuan yang jauh melebihi media yang ada sebelumnya. Selanjutnya, penemuan mesin cetak tersebut meningkatkan jumlah penerbitan berbagai jenis sumber daya informasi tercetak yang memperkaya koleksi perpustakaan.

Sumber daya informasi tercetak telah mendominasi koleksi perpustakaan selama ratusan tahun. Sampai dengan sekarang, sumberdaya ini masih diungkap urgen di perpustakaan dan menjadi objek kajian yang sangat penting dalam bidang ilmu informasi dan perpustakaan. Sumber daya informasi tercetak telah memainkan peran penting dalam memenuhi harapan pemustaka perpustakaan perguruan tinggi dan masih terus digunakan secara luas baik oleh sivitas akademika maupun peneliti.

Harus diakui bahwa pada sejumlah perpustakaan perguruan tinggi di Indonesia, sumber daya informasi tercetak masih menjadi salah satu bentuk informasi terbaik yang digunakan oleh mahasiswa dan dosen. Namun, seiring dengan perkembangan teknologi informasi ada keperluan untuk mengubahnya ke format elektronik berkaitan dengan efisiensi penyimpanan, kemudahan diseminasi dan akses. Transformasi sumber daya informasi ke dalam format elektronik sesuai dengan kebutuhan masyarakat global yang semakin terbiasa dengan sumber daya informasi elektronik, utamanya bagi pemustaka dari kalangan digital native. Perubahan itu tidak mengabaikan manfaat yang diberikan oleh sumber daya informasi tercetak kepada pemustaka, akan tetapi menambah kekayaan dan variasi koleksi perpustakaan.

Sekarang ini, sumber daya informasi tercetak menghadapi persaingan dari sumber informasi elektronik yang jauh lebih cepat dan dapat diandalkan, sehingga persaingan dan transformasi global telah memaksa pengguna untuk beralih ke media elektronik (Kumar \& Gupta, 2013). Realita yang dapat diamati sekarang ini bahwa pemustaka perpustakaan perguruan tinggi mulai berubah dari dirinya sendiri beralih ke sumber daya informasi elektronik, hal itu dapat dilihat dari contoh data pengunjung situs web repositori USU dalam kurun waktu tiga tahun terakhir cenderung meningkat rata-rata $10,2 \%$ per tahun dan download dari e-journal meningkat rata-rata $22,5 \%$ per tahun, sedangkan jumlah pinjaman buku tercetak cenderung menurun $3,9 \%$ per tahun (Perpustakaan USU, 2017).

Sejarah penerbitan elektronik sangat singkat jika dibandingkan dengan penerbitan tradisional seperti halnya sumber daya informasi tercetak, akan tetapi penuh dengan peristiwa yang sangat penting. Penerbitan elektronik pertama sekali muncul pada tahun 1980 dalam bentuk e-mail teks biasa (Bansode, 2013). Penerbitan elektronik pada masa ini terjadi dalam langganan jurnal. Perpustakaan melanggan berbagai judul jurnal dari berbagai penerbit, kemudian penerbit mengirim jurnal dalam file elektronik kepada perpustakaan melalui milis atau $e$-mail, sehingga perpustakaan menerima file elektronik dari judul jurnal yang dilanggan sesuai keberkalaan penerbitannya. Biasanya setelah diterima, perpustakaan akan mencetaknya kembali agar dapat digunakan oleh pemustaka. Akan tetapi setelah mengalami banyak perubahan, akhirnya pada tahun 1994-95 muncullah e-journals yang pertama (Velmurugan \& Radhakrishnan, 2015). (Pettenati, 2002) menyatakan bahwa, jurnal elektronik (e-journal) pertama yang didistribusikan yakni Electronics Letters online by IEEE (Institution of Electrical Engineers). Thanuskodi (2011) menyatakan bahwa karena manfaat prospektif yang disediakan oleh jurnal elektronik, banyak perpustakaan perguruan tinggi telah menerima jurnal elektronik dan berhenti berlangganan jurnal tercetak. Hal yang sama terjadi di Indonesia, bahwa perpustakaan perguruan tinggi umumnya telah melanggan jurnal elektronik dan mulai meninggalkan jurnal tercetak. 
Perkembangan selanjutnya, terlihat betapa teknologi informasi mendorong pertumbuhan informasi yang sangat pesat, khususnya informasi elektronik. Perkembangan teknologi informasi terkini berkaitan dengan e-reader dan perangkat tablet seperti iPad, Kindle dan Nook yang telah mengubah industri penerbitan dan perdagangan buku. Penerbit sekarang memanfaatkan perangkat tersebut dengan harapan untuk lebih menjangkau pengguna termasuk yang pernah tertarik dengan format cetak, agar beralih ke format elektronik atau digital. Sekalipun berbagai judul buku masih tersedia dalam bentuk cetak, akan tetapi peningkatan jumlah buku dalam format elektronik sangat fantastis yang menyebabkan pergeseran cara orang dan perpustakaan dalam membeli buku. E-book telah menjadi fenomena global, dengan perangkat membaca yang tersedia di berbagai negara di seluruh dunia (Weinstein, 2010).

Pemustaka perpustakaan sekarang ini menginginkan data lebih cepat. Mereka tidak punya waktu untuk melihat dan memeriksa halaman demi halaman dalam sebuah buku. Sebaliknya, mereka sangat cepat memaparkan data di internet, sehingga melahirkan berbagai sumber daya informasi elektronik yang sangat banyak dan variatif. Pertumbuhan informasi yang cepat ini telah menimbulkan tantangan baru bagi perpustakaan dan telah menyebabkan perubahan perilaku pemustaka perpustakaan dalam mencari informasi (Kaur \& Mahajan, 2012). Pertumbuhan informasi tersebut berpengaruh secara signifikan terhadap pertumbuhan dan perkembangan koleksi perpustakaan perguruan tinggi. Kemapanan sumber daya informasi berbasis kertas ditantang oleh sumber daya informasi elektronik yang menawarkan cara yang berbeda dalam penyimpanan dan menemubalikkan informasi (Hasugian, 2008) dan sebaliknya dapat menjadi peluang baru yaitu memperkaya ketersediaan sumber daya informasi tercetak yang sebelumnya mendominasi koleksi perpustakaan.

Fenomena umum menunjukkan kecenderungan pemustaka perpustakaan, terutama pada perpustakaan perguruan tinggi menggunakan sumber daya informasi elektronik baik yang bersifat ilmiah maupun yang non-ilmiah semakin meluas, bahkan ada yang memprediksi lebih tinggi dibanding dengan penggunaan sumber daya tercetak. Penelitian Zha, Li, \& Yan (2012) pada sejumlah perpustakaan universitas di Cina menyatakan bahwa terjadi peningkatan penggunaan sumber daya informasi elektronik yang sangat signifikan, sedangkan penggunaan sumber daya informasi tercetak cenderung menurun.

Perpustakaan USU mengalami keadaan yang hampir sama dengan yang terjadi di sejumlah perpustakaan universitas di China. Data penggunaan sumber daya informasi di Perpustakaan USU dalam kurun waktu lima tahun terakhir menunjukkan bahwa penggunaan sumber daya informasi tercetak cenderung menurun, sedangkan data penggunaan sumber daya informasi elektronik mengalami peningkatan yang sangat signifikan (Universitas Sumatera Utara, 2017). Sekalipun terjadi peningkatan penggunaan sumber informasi elektronik dibanding dengan sumber informasi tercetak, namun jika diselidiki lebih lanjut peningkatan itu tidak terjadi untuk semua jenis sumber daya informasi. Penggunaan buku teks, keadaannya justeru terbalik. Data menggambarkan bahwa khusus untuk buku teks, pemanfaatan buku teks tercetak masih cenderung lebih tinggi dari pada $e$-book.

Penggunaan sumber daya informasi tercetak dan elektronik di sejumlah perpustakaan perguruan tinggi masih tetap menjadi objek penelitian, mengingat investasi yang disediakan untuk pengembangan koleksi elektronik jauh lebih besar dari tercetak. Pada hal pemanfaatannya belum tentu sebanding dengan dana yang disediakan untuk membeli atau melanggan sumber daya informasi elektronik. Untuk mengkaji hal tersebut, berbagai penelitian tentang penggunaan sumber daya informasi tercetak dan elektronik telah dilakukan di sejumlah perpustakaan perguruan tinggi.

Penelitian Al-Umut, Soydal, \& Yasar (2010) di Hacettepe University, Ankara Turkey terhadap penggunaan sumber daya informasi elektronik khususnya ebooks menunjukkan 
bahwa ebooks dalam bidang kedokteran yang paling sering digunakan, kemudian diikuti ebooks dalam bidang pendidikan dan bahasa dan sastra, sedangkan ebooks dalam bidang ilmu lainnya jarang bahkan tidak pernah digunakan, karena pemustaka lebih menyukai buku teks tercetak. Temuan penelitian ini menunjukkan bahwa kebijakan pengembangan koleksi $e$ books pada perpustakaan perguruan tinggi tidak selamanya relevan untuk semua bidang ilmu. Pandangan yang menyatakan bahwa pengembangan koleksi perpustakaan perguruan tinggi di masa mendatang lebih berorientasi ke sumber daya informasi elektronik tidak selamanya dibenarkan, sebab masih banyak pemustaka yang lebih suka dengan buku tercetak. Penelitian Zhang \& Kudva (2014) menyatakan bahwa kebanyakan orang, 57,3\% dari total sampel masih hanya membaca buku cetak dan 77,7\% membaca e-book dan buku cetak. Pemustaka mengharapkan perpustakaan perpaduan sumber informasi tercetak dan sumber daya elektronik (hybrid).

Kebijakan pengembangan koleksi perpustakaan perguruan tinggi tidak hanya mempertimbangkan ketersediaan sumbersumber informasi, akan tetapi juga mempertimbangkan faktor anteseden yaitu variabel yang melekat pada diri pemustaka perpustakaan seperti usia, jenis kelamin, jenjang pendidikan, dan sebagainya. Faktor sosiodemografi seperti jenis kelamin, usia, dan sebagainya berpengaruh terhadap penggunaan sumber daya informasi yang tersedia di perpustakaan. Faktor-faktor tersebut sering digunakan sebagai variabel dalam meneliti penggunaan sumber daya informasi di perpustakaan perguruan tinggi.

Gerlich, Drumheller, \& Sollosy (2012) misalnya meneliti tentang perbedaan motivasi membaca (reading motivations) berdasarkan jenis kelamin dan usia di perpustakaan perguruan tinggi. Penelitian Kalmus, Realo, \& Siibak (2011) di University of Tartu, tentang motivasi menggunakan internet berdasarkan faktor sosio-demografis: jenjang pendidikan (education level); bidang ilmu (disciplines); usia (age), jenis kelamin dan etnik. Penelitian Alade, Iyoro, \& Amusa (2014) mengenai kebutuhan yang mendorong mahasiswa mencari berbagai sumber informasi berdasarkan perbedaan departemen/program studi, level atau tingkat (semester), prestasi belajar, usia dan jenis kelamin. Peneliti Lawal-Solarin (2013) menyatakan bahwa mahasiswa laki-laki (53,6\%) lebih sering menggunakan perpustakaan dibanding dengan mahasiswa perempuan $(46,4 \%)$ di Covenant University Library, Ota, Nigeria. Penelitian ini menguatkan temuan peneliti Oyesiku \& Oduwole pada tahun 2004 di Olabisi Onabanjo University Library.

Hasil penelitian di atas menggambarkan bahwa karakteristik demografis pemustaka yang berbeda dapat pula berbeda dalam penggunaan sumber daya informasi yang terdapat di perpustakaan. Temuan penelitian di atas juga menunjukkan bahwa karakteristik pemustaka berdasarkan jenis kelamin juga berhubungan dengan penggunaan sumber daya informasi tercetak maupun elektronik di perpustakaan. Berdasarkan uraian tersebut diajukan pertanyaan yang akan dijawab dalam penelitian ini yaitu: Bagaimanakah kepuasan yang diinginkan dan kepuasan yang diperoleh mahasiswa dari penggunaan sumber daya informasi tercetak dan elektronik di Perpustakaan USU berdasarkan jenis kelamin?

\section{Hipotesis Penelitian}

Untuk menjawab pertanyaan penelitian, diajukan empat hipotesis sebagai berikut:

(1) Terdapat perbedaan kepuasan yang diinginkan (harapan) dari penggunaan sumber daya informasi berdasarkan jenis kelamin

(2) Terdapat perbedaan penggunaan sumber daya informasi berdasarkan jenis kelamin.

(3) Terdapat perbedaan kepuasan yang diperoleh dari penggunaan sumber daya informasi berdasarkan jenis kelamin.

(4) Terdapat kesenjangan antara kepuasan yang diinginkan dan kepuasan yang diperoleh dari penggunaan sumber daya informasi berdasarkan jenis kelamin.

\section{Tujuan Penelitian}

Penelitian bertujuan untuk mendapatkan data dan informasi yang terpercaya dalam 
rangka mengetahui: perbedaan kepuasan yang diinginkan (harapan) pemustaka dari penggunaan sumber daya informasi, perbedaan penggunaan sumber daya informasi baik tercetak maupun elektronik, perbedaan kepuasan yang diperoleh dari penggunaan sumber daya informasi dan untuk membuktikan ada tidaknya kesenjangan antara harapan dan kepuasan yang diperoleh dari penggunaan sumber daya informasi berdasarkan jenis kelamin.

\section{Manfaat Penelitian}

Penelitian ini bermanfaat dalam memperkaya kajian tentang pemustaka perpustakaan yang terus berkembang. Selain itu, penelitian ini diharapkan bermanfaat menghasilkan masukan untuk kebijakan pengembangan koleksi, penyediaan fasilitas dan peningkatan mutu layanan perpustakaan perguruan tinggi dalam rangka menghadapi era digital yang terus berkembang. Hasil penelitian menjadi masukan yang sangat penting kepada pengelola dan manajemen Perpustakaan USU agar tetap menjaga keseimbangan pengembangan koleksi perpustakaan tercetak dengan elektronik.

Tulisan ini merupakan salah satu luaran hasil penelitian berkaitan dengan penggunaan sumber daya informasi di perpustakaan perguruan tinggi. Penelitian sebelumnya mengenai penggunaan perpustakaan perguruan tinggi pernah dilakukan oleh Lawal-Solarin (2013) dan hasilnya menguatkan temuan penelitian Oyesiku \& Oduwole pada tahun 2004 yang menyatakan bahwa mahasiswa laki-laki lebih sering menggunakan perpustakaan dibanding dengan perempuan. Penelitian ini lebih jauh mengkaji pemanfaatan sumber daya informasi tercetak dan elektronik yang tersedia di perpustakaan perguruan tinggi. Penelitian ini secara khusus mengungkapkan kecenderungan mahasiswa menggunakan sumber daya informasi tercetak dan elektronik berdasarkan jenis kelamin. Penelitian merupakan karya orisinal yang belum pernah disajikan sebagai suatu tulisan dalam pertemuan ilmiah maupun pada media publikasi lain. Berdasarkan hasil penelusuran pada sejumlah database jurnal elektronik di Indonesia, penelitian sejenis belum pernah dilakukan, sehingga dapat dinyatakan sebagai penelitian baru di bidang perpustakaan dan sain informasi.

\section{B. TINJAUAN PUSTAKA}

Teori value-expectancy (nilai-harapan) merupakan salah satu teori komunikasi massa yang sering digunakan untuk meneliti dampak atau pengaruh penggunaan media dilihat dari keperluan pengguna. Teori ini menyatakan bahwa sikap seseorang terhadap segmensegmen media ditentukan oleh nilai yang mereka anut dan evaluasi tentang media tersebut (Morissan, 2013). Teori ini menjelaskan sikap pemustaka terhadap sejumlah media akan ditentukan oleh kepercayaan tentang penilaian pemustaka terhadap media tersebut.

Teori value-expectancy (teori nilaiharapan) merupakan hal yang sangat penting bagi teori uses and gratification, karena teori ini mampu memberi dukungan dan memperluas landasan teori uses and gratification. Bahkan berbagai penelitian dengan pendekatan teori uses and gratifications dilakukan dengan menggunakan dukungan teori valueexpectancy. Gabungan dari teori valueexpectancy dengan uses and gratifications merupakan suatu perkembangan yang sangat menjanjikan dalam penelitian penggunaan media(Shin, 2011).

Kelebihan teori value-expectancy dari teori uses and gratification sebagai teori induknya terletak pada cara pengukuran kepuasan yaitu analisis terhadap kepuasan yang diharapkan atau diinginkan atau gratification sought (GS) dan kepuasan yang diperoleh atau gratification obtained (GO) dari penggunaan sumber daya informasi. Gratifikasi atau kepuasan dalam teori value-expectancy dan dalam teori uses and gratification secara substansi adalah sama, namun dimensi kepuasan tersebut diukur dari dua konsep gratifikasi. $G S$ adalah kepuasan yang diinginkan individu ketika akan mengkonsumsi atau menggunakan suatu jenis media tertentu, yang sering disebut sebagai harapan (expectancy), sedangkan $G O$ adalah kepuasan yang didapat seseorang setelah menggunakan salah satu jenis media tertentu, 
yang sering disebut sebagai nilai (McQuail, 2010). Media yang dimaksudkan dalam hal ini seluruh dokumen yang merekam informasi dan pengetahuan, termasuk buku, jurnal/majalah dan koleksi elektronik lainnya. Operasionalisasi dari teori ini membandingkan kedua konsep GS dan $G O$, sehingga dapat diketahui kesenjangan kepuasan (gratifications discrepancy) dengan melihat perbedaan perolehan kepuasan yang terjadi antara skor atau nilai dari $G S$ dan $G O$ dalam mengkonsumsi media tertentu.

Kerangka dasar teori value-expectancy terdiri dari beberapa unsur antara lain: GS, GO, penggunaan media (media use) dan kesenjangan kepuasan (gratifications discrepancy). Operasional pengukurannya dengan membandingkan mean GS dan GO dengan ketentuan: (a) jika GS > GO dan selisih nilai mean adalah negatif, artinya bahwa media atau sumber daya informasi yang digunakan tidak memuaskan pemustakanya, (b) Jika GS = GO dan selisih nilai mean adalah positif atau nol, artinya sumber daya informasi yang digunakan memuaskan pemustakanya, dan (c) Jika GS < GO dan selisih nilai mean tersebut adalah positif, artinya sumber daya informasi yang digunakan sangat memuaskan pemustakanya (Laura, 2013).

\section{METODE PENELITIAN}

Penelitian ini tergolong ke dalam penelitian asosiatif. Penelitian ini menggunakan metode survei dengan pendekatan kuantitatif. Pendekatan kuantitatif menuntut peneliti melakukan pengamatan yang dapat dikuantifikasi dan kemudian dianalisis agar dapat memberikan dasar argumen mengenai makna pengamatan yang relatif terhadap posisi teoritis (Sugiyono, 2017).

Berdasarkan model teori value-expectancy sebagaimana diuraikan di atas dibangun kerangka pemikiran untuk penelitian ini. Mahasiswa sebagai pemustaka merupakan komponen penting dalam sistem perpustakaan perguruan tinggi, tanpa pemustaka perpustakaan tidak berarti apa-apa, sehingga pemustaka menjadi variabel penting dalam penelitian ini. Sebaliknya, perpustakaan tanpa ketersediaan sumber daya informasi tidaklah memiliki arti. Tugas utama perpustakaan mempertemukan pemustaka dengan sumber daya informasi yang menjadi koleksi perpustakaan.

Mahasiswa sebagai pemustaka perpustakaan memiliki karakteristik demografis yang berbeda. Perbedaan karakteristik demografis mahasiswa berhubungan dengan kebutuhan informasi dan pola penggunaan sumber daya informasi yang tersedia di perpustakaan. Mahasiswa yang berbeda karakteristik demografisnya dapat berbeda kepuasan (gratifikasi) yang diinginkan (harapan) dari penggunaan sumber daya informasi, dapat berbeda pola dalam menggunakan sumber daya informasi, dan dapat pula berbeda kepuasan yang diperoleh setelah menggunakan sumber daya informasi tertentu.

Mahasiswa sebagai pengguna perpustakaan memiliki kontribusi aktif dalam merespon layanan perpustakaan yaitu menggunakan seluruh sumber daya informasi yang tersedia. Mahasiswa bebas memilih untuk menggunakan atau tidak menggunakan berbagai jenis dan bentuk sumber informasi di perpustakaan. Seluruh sumber informasi yang tersedia di perpustakaan sifatnya opsional atau pilihan. Mahasiswa akan menggunakan sumber daya informasi untuk memenuhi kebutuhannya dan apabila kebutuhannya terpenuhi, maka mereka akan mengalami gratifikasi atau kepuasan. Sesuai teori value-expectancy dan alur berpikir yang telah dipaparkan di atas, desain kerangka konsep penelitian digambarkan seperti pada Gambar-1.

Populasi penelitian ini seluruh mahasiswa program sarjana (S1) yang terdaftar sebagai anggota perpustakaan dan pernah meminjam buku di Perpustakaan USU. Berdasarkan data yang diperoleh ada 47 program studi sarjana di USU, dengan perincian 26 program studi bidang ilmu eksakta dan 21 program studi bidang ilmu non-eksakta. Jumlah mahasiswa program sarjana kumulatif sampai dengan bulan April 2018 yang terdaftar sebagai anggota di Perpustakaan USU sebesar 32.684, akan tetapi dari jumlah tersebut yang pernah meminjam buku di Perpustakaan USU sebesar 16.919 orang atau sekitar $52,3 \%$, sehingga populasi 
penelitian ini sebesar 16.919 orang. Sampel ditetapkan menggunakan rumus Taro Yamane. Jumlah sampel penelitian ini sebesar 391 dengan perincian dari program studi bidang ilmu eksakta sebesar $210(53,7 \%)$ dan dari program studi bidang ilmu non eksakta sebesar $181(46,3 \%)$.

Kuesioner dipakai untuk menjaring dan memperoleh data yang dibutuhkan dalam penelitian ini. Bentuk kuesioner yang digunakan Skala Likert. Sebelum diedarkan dilakukan uji instrumen mencakup uji validitas dan reliabilitas. Uji reliabilitas dan validitas terhadap instrumen penelitian dilakukan menggunakan program aplikasi komputer SPSS versi 17. Hasil uji validitas dan reliabilitas terhadap angket penelitian menunjukkan semua butir angket dinyatakan valid dan reliabel karena nilai korelasi (r) lebih besar dari 0,312 atau $\mathrm{r}>0,312$ dan koefisien keandalan (Cronbach Alpha) lebih besar dari 0,6 $(>0,6)$.

Program yang digunakan untuk pengolahan data berupa program aplikasi Lisrel versi 8.8. Analisis data memakai cara analisis statistik Chi-Kuadrat, multivariate analysis of variance (MANOVA) dan analisis jalur (Path analysis). Analisis Chi-Kuadrat dimaksudkan untuk melihat perbedaan penggunaan sumber daya informasi berdasarkan karakteristik responden yaitu jenis kelamin.

\section{HASILDAN PEMBAHASAN \\ 1. Gambaran Responden Berdasarkan Jenis kelamin}

Berdasarkan data, persentase responden sesuai jenis kelamin adalah $131(33,51 \%)$ lakilaki dan $260(66,49 \%)$ perempuan. Jumlah responden seluruhnya adalah 391 orang. Data ini mengindikasikan bahwa sampai dengan bulan April 2018 pengguna sumber daya informasi yang tersedia di Perpustakaan USU paling banyak perempuan.

\section{Perbedaan Kepuasan yang Diinginkan dari Pengunaan Sumber Daya Informasi Berdasarkan Jenis Kelamin}

Hipotesis pertama yang diuji berupa, hipotesis nol $\left(\mathrm{H}_{\mathrm{o}}\right)$, tidak terdapat perbedaan kepuasan yang diinginkan yang signifikan secara statistik dari penggunaan sumber daya informasi berdasarkan jenis kelamin. Sedang hipotesis alternatif $\left(\mathrm{H}_{1}\right)$, terdapat perbedaan kepuasan yang diinginkan yang signifikan secara statistik dari penggunaan sumber daya informasi berdasarkan jenis kelamin.

Untuk menguji perbedaan kepuasan yang diinginkan dari penggunaan sumber daya informasi berdasarkan jenis kelamin mahasiswa, kriteria atau ukuran tingkat signifikansi yang dipakai dalam penelitian ini, adalah $\alpha=0,05$, sehingga apabila nilai probabilitas atau signifikansi (Sig) dari karakteristik demografis (KD) yaitu jenis kelamin pengguna dikali dengan penggunaan sumber daya informasi atau media use (MD) atau $\left(\mathrm{KD}^{*} \mathrm{MD}\right) \geq 0,05$ (lebih besar atau sama dengan 0,05), maka $\mathrm{H}_{0}$ diterima dan $\mathrm{H}_{1}$ ditolak. Namun, apabila nilai probabilitas atau Sig.

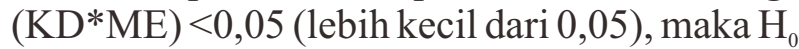
ditolak dan $\mathrm{H}_{1}$ diterima.

Hasil uji menggunakan multivariate analysis of variance (MANOVA) untuk variabel kepuasan yang diinginkan (harapan) dalam penggunaan sumber daya informasi berdasarkan jenis kelamin dapat dilihat pada Tabel 1.

Sesuai data dari hasil uji dalam Tabel 1 diketahui bahwa nilai signifikansi atau Sig 0,699, dan nilai Sig 0,699 tersebut lebih besar dari tingkat signifikansi $\alpha=0,05$. Sehingga, sesuai kriteria atau ukuran penerimaan dan penolakan hipotesis di atas dapat disimpulkan: bahwa tidak terdapat perbedaan kepuasan yang diinginkan oleh pemustaka yang signifikan secara statistik dari penggunaan sumber daya informasi berdasarkan jenis kelamin. Hipotesis penelitian yang menyatakan, terdapat perbedaan kepuasan yang diinginkan yang signifikan dari penggunaan sumber daya informasi berdasarkan jenis kelamin pemustaka di Perpustakaan USU ditolak.

Hasil pengujian ini sinkron dengan data deskriptif yang menyatakan bahwa $81,68 \%$ dari 131 responden laki-laki dan 80,13\% dari 307 responden perempuan memiliki keinginan atau harapan yang tinggi untuk menggunakan sumber daya informasi tercetak maupun elektronik yang tersedia di perpustakaan. Data 
ini menggambarkan bahwa pada umumnya responden laki-laki dan perempuan memiliki motivasi yang kuat menggunakan, mengakses atau membaca berbagai jenis sumber daya informasi baik tercetak maupun elektronik dari Perpustakaan USU. Memang terdapat perbedaan, namun perbedaan itu tidak begitu besar. Ada kecenderungan bahwa mahasiswa laki-laki memiliki motivasi yang lebih kuat dibanding dengan mahasiswa perempuan dalam mengakses berbagai jenis sumber daya informasi dari Perpustakaan USU.

\section{Perbedaan Penggunaan Sumber Daya Informasi Berdasarkan Jenis kelamin}

Hipotesis kedua yang diuji adalah, hipotesis nol $\left(\mathrm{H}_{\mathrm{o}}\right)$ menyatakan, tidak terdapat perbedaan penggunaan sumber daya informasi yang signifikan berdasarkan jenis kelamin pengguna di Perpustakaan USU, sedangkan hipotesis alternatif $\left(\mathrm{H}_{1}\right)$ menyatakan, terdapat perbedaan penggunaan sumber daya informasi yang signifikan berdasarkan jenis kelamin pemustaka di Perpustakaan USU.

Untuk menguji perbedaan penggunaan sumber daya informasi berdasarkan jenis kelamin, kriteria signifikansi yang dipakai untuk penelitian ini adalah $\alpha=0,05$ sehingga bila nilai probabilitas atau Asymp. Sig. (2-sided) dari Pearson Chi-Square $\geq 0,05$ maka $\mathrm{H}_{0}$ diterima dan $\mathrm{H}_{1}$ ditolak. Dalam hal ini, hubungan yang terjadi antara dua variabel kategori tidak signifikan secara statistik. Namun, apabila nilai probabilitas atau Asymp. Sig. (2-sided) dari Pearson Chi-Square $<0,05$ maka $\mathrm{H}_{0}$ ditolak dan $\mathrm{H}_{1}$ diterima. Dalam hal ini, hubungan yang terjadi antara dua variabel kategori signifikan secara statistik.

Hasil pengujian secara statistik menggunakan uji chi-square Pearson untuk variabel penggunaan sumber daya informasi berdasarkan jenis kelamin di Perpustakaan USU dapat dilihat pada Tabel 2. Berdasarkan data hasil pengujian dalam tersebut diketahui nilai Asymp. Sig. (2-sided) sebesar 0,263, di mana nilai Asymp. Sig. (2-sided) 0,263, lebih besar dari tingkat signifikansi $\alpha=0,05$, maka sesuai kriteria signifikansi di atas dapat disimpulkan bahwa hubungan yang terjadi antara jenis kelamin terhadap penggunaan sumber daya informasi tidak signifikan secara statistik, sehingga hipotesis penelitian yang menyatakan, terdapat perbedaan penggunaan sumber daya informasi yang signifikan berdasarkan jenis kelamin di Perpustakaan USU ditolak.

Hasil pengujian ini sinkron dengan analisis data deskriptif yang menunjukkan bahwa untuk kategori sering, nilai persentase keseringan responden laki-laki $(33,59 \%)$ menggunakan sumber daya informasi baik tercetak maupun elektronik tidak jauh berbeda dengan nilai persentase keseringan responden perempuan $(32,60 \%)$. Namun demikian, data ini mengindikasikan ada kecenderungan mahasiswa laki-laki lebih sering menggunakan, mengakses atau membaca berbagai jenis sumber daya informasi baik tercetak maupun elektronik dari Perpustakaan USU dibanding dengan mahasiswa perempuan.

\subsection{Perbedaan Penggunaan Sumber Daya Informasi Tercetak Berdasarkan Jenis kelamin}

Hasil pengujian terhadap perbedaan penggunaan sumber daya informasi tercetak berdasarkan jenis kelamin responden dapat dilihat pada Tabel 3. Hasil pengujian dalam tabel tersebut, menunjukkan bahwa nilai Asymp. Sig. (2-sided) sebesar 0,665, di mana nilai Asymp. Sig. (2-sided) 0,665, lebih besar dari tingkat signifikansi $\alpha=0,05$, maka sesuai kriteria atau ukuran signifikansi di atas dapat disimpulkan bahwa hubungan yang terjadi antara jenis kelamin terhadap penggunaan sumber daya informasi tercetak tidak signifikan secara statistik, sehingga sub hipotesis penelitian yang menyatakan, terdapat perbedaan penggunaan sumber daya informasi tercetak yang signifikan berdasarkan jenis kelamin di Perpustakaan USU ditolak.

Hasil pengujian ini sinkron dengan analisis data deskriptif dimana untuk kategori sering, $14,66 \%$ responden perempuan menyatakan sering menggunakan sumber daya informasi tercetak di Perpustakaan USU dan responden laki-laki hanya $11,45 \%$. Data ini menggambarkan bahwa tingkat keseringan mahasiswa perempuan dan laki-laki menggunakan sumber daya informasi tercetak 
baik di Perpustakaan USU tidak jauh berbeda. Mahasiswa perempuan cenderung lebih sering menggunakan sumber daya informasi tercetak dibanding dengan mahasiswa laki-laki di Perpustakaan USU.

\subsection{Perbedaan Penggunaan Sumber Daya Informasi Elektronik Berdasarkan Jenis kelamin}

Hasil pengujian terhadap perbedaan penggunaan sumber daya informasi elektronik berdasarkan jenis kelamin dapat dilihat pada Tabel 4. Berdasarkan hasil pengujian diketahui nilai Asymp. Sig. (2-sided) sebesar 0,477, di mana nilai Asymp. Sig. (2-sided) 0,477, lebih besar dari tingkat signifikansi $\alpha=0,05$, maka sesuai kriteria signifikansi di atas dapat disimpulkan bahwa hubungan yang terjadi antara jenis kelamin terhadap penggunaan sumber daya informasi elektronik tidak signifikan secara statistik. Sehingga, sub hipotesis penelitian yang menyatakan, terdapat perbedaan penggunaan sumber daya informasi elektronik yang signifikan berdasarkan jenis kelamin di Perpustakaan USU ditolak.

Hasil pengujian ini sinkron dengan data deskriptif yaitu $37,40 \%$ responden laki-laki menyatakan sering menggunakan sumber daya informasi elektronik di Perpustakaan USU sedangkan responden perempuan hanya $32,57 \%$. Berdasarkan data tersebut diinterpretasikan bahwa tingkat keseringan mahasiswa laki-laki dan perempuan menggunakan berbagai jenis sumber daya informasi elektronik di Perpustakaan USU tidak jauh berbeda. Mahasiswa laki-laki cenderung lebih sering menggunakan sumber daya informasi elektronik di Perpustakaan USU dibanding dengan mahasiswa perempuan.

\section{Perbedaan Kepuasan yang Diperoleh dari Pengunaan Sumber Daya Informasi Berdasarkan Jenis kelamin}

Hipotesis ketiga yang diuji adalah, hipotesis nol $\left(\mathrm{H}_{\mathrm{o}}\right)$, tidak terdapat perbedaan kepuasan yang diperoleh yang signifikan secara statistik dari penggunaan sumber daya informasi berdasarkan jenis kelamin, sedangkan hipotesis alternatif $\left(\mathrm{H}_{1}\right)$, terdapat perbedaan kepuasan yang diperoleh yang signifikan secara statistik dari penggunaan sumber daya informasi berdasarkan jenis kelamin.

Untuk menguji perbedaan kepuasan yang diperoleh dari penggunaan sumber daya informasi berdasarkan jenis kelamin, kriteria signifikansi yang dipakai dalam penelitian ini sebesar $\alpha=0,05$, sehingga bila nilai probabilitas atau signifikansi (Sig) dari karakteristik demografis (KD) pengguna yaitu jenis kelamin dikali dengan penggunaan sumber daya informasi atau media use (MD) atau (KD*MD) $\geq 0,05$ maka $\mathrm{H}_{0}$ diterima dan $\mathrm{H}_{1}$ ditolak. Namun, apabila nilai probabilitas atau Sig. (KD*ME) $<0,05$ maka $\mathrm{H}_{0}$ ditolak dan $\mathrm{H}_{1}$ diterima.

Hasil pengujian menggunakan uji multivariate analysis of variance (MANOVA) untuk variabel kepuasan yang diperoleh setelah menggunakan sumber daya informasi berdasarkan jenis kelamin dapat dilihat pada Tabel-5. Berdasarkan data dari hasil pengujian dalam tabel tersebut, diketahui bahwa nilai signifikansi atau Sig adalah 0,999, di mana nilai Sig 0,999 tersebut lebih besar dari tingkat signifikansi $\alpha=0,05$. Sesuai kriteria penerimaan dan penolakan hipotesis di atas dapat dinyatakan: bahwa tidak terdapat perbedaan kepuasan yang diperoleh yang signifikan secara statistik dari penggunaan sumber daya informasi berdasarkan jenis kelamin, dengan demikian hipotesis penelitian ditolak.

Hasil pengujian sinkron dengan data deskriptif yaitu $66,78 \%$ responden perempuan menyatakan sangat puas menggunakan berbagai jenis sumber daya informasi baik tercetak maupun elektronik yang tersedia di Perpustakaan USU dan $61,07 \%$ responden lakilaki menyatakan hal yang sama. Berdasarkan data tersebut diinterpretasikan bahwa perbedaan kepuasan yang diperoleh mahasiswa laki-laki dan perempuan setelah menggunakan, mengakses atau membaca berbagai jenis sumber daya informasi tidak begitu besar, namun kepuasan yang diperoleh mahasiswa perempuan cenderung lebih tinggi dari kepuasan yang diperoleh mahasiswa laki-laki. 


\section{Kesenjangan Gratification Sought dengan Gratification Obtained Berdasarkan Jenis kelamin}

Hasil pengujian kesenjangan antara GS dengan GO dari penggunaan sumber daya informasi berdasarkan jenis kelamin di Perpustakaan USU dapat dilihat dalam Tabel-6. Berdasarkan data dari hasil pengujian dalam tabel tersebut, diketahui bahwa nilai signifikansi atau Sig sebesar 0,911, di mana nilai Sig 0,911 lebih besar dari tingkat signifikansi $\alpha=0,05$. Sesuai kriteria penerimaan dan penolakan hipotesis di atas, dinyatakan bahwa tidak terdapat perbedaan yang signifikan secara statistik kesenjangan antara kepuasan yang diinginkan (GS) dengan kepuasan yang diperoleh $(\mathrm{GO})$ dari penggunaan sumber daya informasi berdasarkan jenis kelamin di Perpustakaan USU, dengan demikian hipotesis penelitian ditolak. Oleh karena itu, dapat dinyatakan bahwa penggunaan sumber daya informasi tercetak dan elektronik yang tersedia di Perpustakaan USU memuaskan mahasiswa baik laki-laki maupun perempuan.

\section{Pembahasan}

Hasil penelitian ini tidak jauh berbeda dengan penelitian Gerlich, Drumheller \& Sollosy (2012) tentang motivasi membaca menggunakan pendekatan teori uses and gratifications yang menjelaskan bahwa, tidak terdapat perbedaan motivasi yang mendorong seseorang untuk membaca sejumlah buku berdasarkan gender di perguruan tinggi. Artinya, faktor jenis kelamin tidak berpengaruh secara signifikan mendorong seseorang untuk menggunakan berbagai sumber daya informasi di perpustakaan perguruan tinggi. Hasil penelitian ini juga sinkron dengan penelitian Simmonds \& Andaleeb (2001), dan penelitian Sivathaasan (2013) yang menggunakan sejumlah karakteristik demografi pengguna perpustakaan seperti: jenis kelamin (gender/sex), jenjang pendidikan, program studi, dan spesialisasi dalam penelitiannya menunjukkan bahwa, penggunaan sumber daya informasi di perpustakaan perguruan tinggi berdasarkan gender tidak berbeda, akan tetapi berdasarkan jenjang pendidikan, program studi, dan spesialisasi cenderung berbeda.

Selain itu, hasil penelitian ini juga hampir sama dengan penelitian Kassim (2009) yang meneliti penggunaan perpustakaan berdasarkan karakteristik demografi pengguna, hasil menyatakan bahwa terdapat perbedaan penggunaan koleksi perpustakaan oleh mahasiswa berdasarkan fakultas dan program studi yang berbeda, sedangkan dari faktor gender cenderung tidak berbeda. Dengan demikian, hasil penelitian ini mendukung penelitian yang pernah dilakukan sebelumnya di tempat yang berbeda. Sehingga, kecenderungan keseringan penggunaan sumber daya informasi elektronik sebagaimana dikemukakan dalam penelitian Zha, Li dan Yan (2012), dan penelitian Al-Umut, Soydal dan Tonta (2010) pada uraian sebelumnya, ternyata tidak berlaku untuk seluruh jenis sumber daya informasi. Khusus untuk buku teks dan buku pendukung lainnya, penggunaannya justru sebaliknya. Artinya, pengguna lebih suka menggunakan buku teks tercetak dan buku pendukung tercetak lainnya dibanding dengan buku elektronik (ebooks).

\section{E. KESIMPULAN}

Mahasiswa laki-laki maupun perempuan memiliki motivasi yang kuat menggunakan berbagai jenis sumber daya informasi baik tercetak maupun elektronik dari Perpustakaan USU, namun ada kecenderungan mahasiswa perempuan lebih sering menggunakan sumber daya informasi tercetak dibanding dengan mahasiswa laki-laki, sebaliknya mahasiswa laki-laki cenderung lebih sering menggunakan sumber daya informasi elektronik dibanding dengan mahasiswa perempuan. Ketersediaan sumber daya informasi tercetak dan elektronik di Perpustakaan USU memenuhi kebutuhan mahasiswa dan penggunaannya memuaskan mahasiswa baik laki-laki maupun perempuan. Faktor sosio demografis jenis kelamin tidak signifikan berpengaruh terhadap penggunaan sumber daya informasi baik tercetak maupun elektronik di Perpustakaan USU. Namun mengingat mahasiswa USU yang heterogen 
terdiri dari beragam suku yang berasal dari 35 Provinsi di Indonesia juga yang berasal dari etnik Cina dan India, baik yang berasal dari Indonesia maupun dari negara asing.

\section{ACKNOWLEDGMENTS:}

Ucapan terima kasih dihaturkan kepada Rektor Universitas Sumatera Utara yang merilis lima skema penelitian dalam program kerjanya yaitu penelitian dosen muda, dasar, terapan, unggulan universitas dan penciptaan dan penyajian seni yang bingkai dalam jargon TALENTA. Tulisan ini adalah salah satu luaran hasil penelitian dasar TALENTA yang didanai dari PNBP Universitas Sumatera Utara tahun 2018.

\section{DAFTAR PUSTAKA}

Al-Umut, Soydal, I., \& Yasar, T. (2010). Analysis of e-book use: The case of ebrary. Department of Information Management.

Alade, V. A., Iyoro, A. O., \& Amusa, O. I. (2014). Library use characteristics of undergraduates in Nigeria University of Science and Technology. International Research : Journal of Library and Information Science, 4(1), 15-27. Retrieved from https://gateway.library. qut.edu.au/login?url=https://search.proqu est.com/docview/1544762092?accountid $=13380 \% 0$ Ahttps://qut.primo.exlibrisgrou p.com/discovery/openurl?institution $=61 \mathrm{Q}$ UT_INST\&vid=61QUT_INST:61QUT\& genre $=$ article $\&$ issn $=\&$ title $=$ Library + Use + Character

Bansode, S. Y. (2013). Use and impact of electronic journals on the users of University of Pune, Pune, India. Library Philosophy \& Practice, 1-8. Retrieved from http://digitalcommons.unl.edu/ libphilprac/847

Gerlich, R. N., Drumheller, K., \& Sollosy, M. (2012). The reading motives scale: A uses and gratifications study of what drives people to read. Academy of Marketing Studies Journal, 16(Special Issue), 95-107.
Hasugian, J. (2008). Penelusuran online dan ketersediaan sumber daya informasi elektronik. Pustaha, 4(1 (Juni 2018)), $12-20$.

Kalmus, V., Realo, A., \& Siibak, A. (2011). Motives for internet use and their relationships with personality traits and socio-demographic factors. TramesJournal of the Humanities and Social Sciences, 15 (4), 385-403. https://doi.org/10.3176/tr.2011.4.04

Kassim, N. A. (2009). Evaluating users' satisfaction on academic library performance. Malaysian Journal of Library and Information Science, 14(2), 101-115. Retrieved from http://ejournal.um.edu.my/filebank/published_art icle/2396/750.pdf

Kaur, H., \& Mahajan, P. (2012). Information seeking behavior and awareness about the quality of research in this era of 'E': A survey. International Journal of Information Dissemination and Technology, 2(4), 262. Retrieved from http://search.proquest.com/openview/31d 4546f3e99934eccc9c83da2e0f1c4/1?pqorigsite $=$ gscholar

Kumar, A., \& Gupta, D. K. (2013). From print to electronic: An analytical study of changing preference among users of health science libraries in Haryana, Chandigarh and Delhi. International Journal of Information Dissemination and Technology, 3(1), 76. Retrieved from http://search.proquest.com/openview/a $7 \mathrm{a}$ 617a485cd76545b4698983b3b24b4/1?pq -origsite $=$ gscholar

Laura, E. (2013). Kepuasan pendengar terhadap program Sonora News di Radio Sonora Surabaya. Jurnal E-Komunikasi, 1(1 (2013)).

Lawal-Solarin, E. (2013). Understanding students information needs and role of academic libraries: A case study of Covenant University Library, Ota, Nigeria. Journal of International Resources Management, 3(2), 26-33. 
McQuail, D. (2010). The reading motives scale: $A$ uses and gratifications study of what drives people to read. London: Sage.

Morissan. (2013). Use of an academic library: A survey on the Olabisi Onabanjo University Libraries. Jakarta: Kencana.

Perpustakaan USU. (2017). Laporan akuntabilitas kinerja instansi pemerintah. Medan.

Pettenati, C. (2002). Electronic publishing at the end of 2001. Advanced Technology and Particle Physics, 525-533. https://doi.org/10.1142/9789812776464_0 076

Shin, D.-H. (2011). Understanding e-book users: Uses and gratification expectancy model. New Media and Society, 13(2), 260-278. https://doi.org/10.1177/ 1461444810372163

Simmonds, P. L., \& Andaleeb, S. S. (2001). Usage of academic libraries: The role of service. Library Trends, 49(4), 626-634. Retrieved from http://www.libqual.org/ documents/admin/Simmonds.pdf

Sivathaasan, N. (2013). Personal characteristics and use of library facilities: a special reference to Faculty of Management Studies and Commerce University of Jaffna Sri Lanka. European Journal of Business and Innovation Research, 1(1), 72-79.

Sugiyono. (2017). Metode penelitian pendidikan, pendekatan kualitatif, kuantitatif, dan $R$ \& D. https://doi.org/ 10.1017/CBO9781107415324.004
Thanuskodi, S. (2011). User awareness and use of e-journals among education Faculty Members in Chennai: A survey. International Research: Journal of Library \& Information Science, 1(1), 1-13. Retrieved from http://irjlis.com/userawareness-use-e-journals-facultychennai/

Universitas Sumatera Utara. (2017). Laporan akuntabilitas kinerja instansi pemerintah. Medan.

Velmurugan, C., \& Radhakrishnan, N. (2015). Electronic publishing : A powerful tool for Academic Institutions in the Electronic Environment. International Journal of Library Science and Information Management (IJLSIM), I((1) Jul-Sep, 2015), 10-18.

Weinstein, A. (2010). A look at global expansion for e-books. Publishing Research Quarterly, 26(1), 11-15. https://doi.org/ 10.1007/s12109-010-9148-5

Zha, X., Li, J., \& Yan, Y. (2012). Understanding usage transfer from print resources to electronic resources : A survey of users of Chinese University Libraries. Serials Review, 38(2), 83-98. https://doi.org/ 10.1016/j.serrev.2012.04.002

Zhang, Y., \& Kudva, S. (2014). The reading motives scale: A uses and gratifications study of what drives people to read. Journal of The Association For Information Science and Technology, 65(8), 1695-1706.

Zimmerman, M. (2010). Periodicals: print or electronic? New Library World, 111(9/10), 426-433. 


\section{DAFTAR GAMBAR}

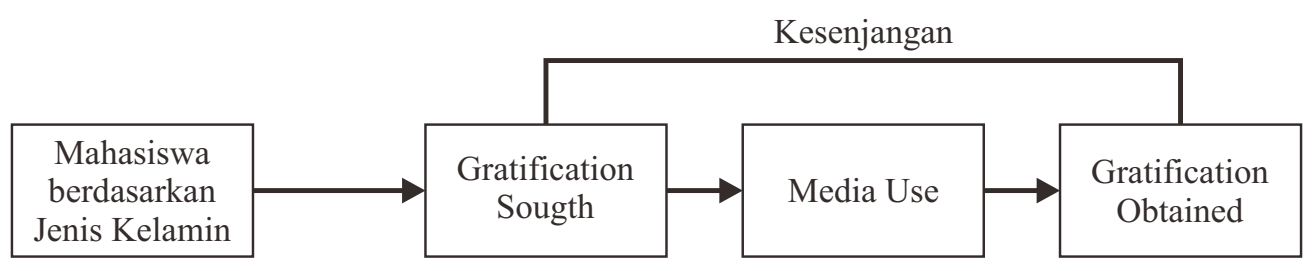

Gambar 1. Desain Penelitian

\section{DAFTAR TABEL}

Tabel-1: Perbedaan GS Berdasarkan Jenis kelamin Pengguna

\begin{tabular}{lrrrrr}
\multicolumn{1}{c}{ Variable } & $\begin{array}{c}\text { Type III Sum of } \\
\text { Squares }\end{array}$ & df & $\begin{array}{c}\text { Mean } \\
\text { Square }\end{array}$ & F & Sig. \\
\hline Jenis kelamin/Jenis Kelamin (JK) & .012 & 1 & .012 & .079 & .779 \\
\hline $\begin{array}{l}\text { Penggunaan Sumber Daya Informasi } \\
\text { atau MediaUse (MU) }\end{array}$ & 5.484 & 2 & 2.742 & 18.208 & .000 \\
\hline $\mathrm{JK} * \mathrm{MU}$ & & & & & .023 \\
\hline a. R Squared $=.083$ (Adjusted R Squared $=.075)$ & & & .023 & .699 \\
\hline
\end{tabular}

Tabel-2: Perbedaan Penggunaan Sumber Daya Informasi Berdasarkan Jenis kelamin

\begin{tabular}{lcccr}
\hline & Value & df & Asymp. Sig. (2-sided) & .263 \\
\hline Pearson Chi-Square & $2.673^{\mathrm{a}}$ & 2 & & .26 \\
\hline
\end{tabular}

Tabel-3: Perbedaan Penggunaan Sumber Daya Informasi Tercetak Berdasarkan Jenis kelamin

\begin{tabular}{lcrrr}
\hline & Value & df & Asymp. Sig. (2-sided) & \\
\hline Pearson Chi-Square & $.815^{\text {a }}$ & 2 & .665 \\
\hline
\end{tabular}

Tabel-4: Perbedaan Penggunaan Sumber Daya Informasi Elektronik Berdasarkan Jenis kelamin

\begin{tabular}{lcccc}
\hline & Value & df & Asymp. Sig. (2-sided) & \\
\hline Pearson Chi-Square & $1.480^{\mathrm{a}}$ & 2 & .477 \\
\hline
\end{tabular}


Tabel-5: Perbedaan Gratification Obtained Berdasarkan Jenis kelamin

\begin{tabular}{cccccc}
\hline Variabel & $\begin{array}{c}\text { Type III Sum of } \\
\text { Squares }\end{array}$ & df & $\begin{array}{c}\text { Mean } \\
\text { Square }\end{array}$ & F & Sig. \\
\hline Jenis Kelamin (JK) & .273 & 1 & .273 & 1.249 & .264 \\
\hline $\begin{array}{c}\text { Penggunaan Sumber Daya Informasi } \\
\text { atau MediaUse (MU) }\end{array}$ & 8.105 & 2 & 4.052 & 18.572 & .000 \\
\hline Jenis * MU & 3.339 & 1 & 3.339 & .000 & .999 \\
\hline a. R Squared $=.093$ (Adjusted R Squared $=.084)$ &
\end{tabular}

a. R Squared $=.093$ (Adjusted R Squared $=.084)$

Tabel-6: Uji Kesenjangan GS dan GO berdasarkan Jenis Kelamin

\begin{tabular}{lrrrrr}
\hline \multicolumn{1}{c}{ Kesenjangan } & $\begin{array}{c}\text { Sum of } \\
\text { Squares }\end{array}$ & df & \multicolumn{1}{c}{$\begin{array}{c}\text { Mean } \\
\text { Square }\end{array}$} & \multicolumn{1}{c}{ F } & \multicolumn{2}{c}{ Sig. } \\
\hline Between Groups & .002 & 1 & .002 & .012 & .911 \\
Within Groups & 68.817 & 436 & .158 & & \\
Total & 68.819 & 437 & & & \\
\hline
\end{tabular}

